\title{
OPEN Author Correction: Near-infrared tunable metalens based on phase change material $\mathrm{Ge}_{2} \mathrm{Sb}_{2} \mathrm{Te}_{5}$
}

Wei Bai $\odot$, Ping Yang, Jie Huang, Dingbo Chen, Jingjing Zhang, Zhaojian Zhang, Junbo Yang \& Bing Xu

Correction to: Scientific Reports https://doi.org/10.1038/s41598-019-41859-x, published online 29 March 2019

The original version of this Article contained an error in the title and Introduction of the paper where " $\mathrm{Ge}_{2} \mathrm{Sb}_{2} \mathrm{Te}_{5}$ " was incorrectly given as " $\mathrm{Ge}_{2} \mathrm{Se}_{2} \mathrm{Te}_{5}$ ".

As a result, in the Introduction,

"Among them, the chalcogenide compound $\mathrm{Ge}_{2} \mathrm{Se}_{2} \mathrm{Te}_{5}$ (GST) which has remarkable fast switching speed (nanosecond or less) ${ }^{42}$, high switching robustness (potentially up to $10^{15} \mathrm{cycles}^{43}$, is one of the most prevalent phase change materials."

now reads,

"Among them, the chalcogenide compound $\mathrm{Ge}_{2} \mathrm{Sb}_{2} \mathrm{Te}_{5}$ (GST) which has remarkable fast switching speed (nanosecond or less) ${ }^{42}$, high switching robustness (potentially up to $10^{15}$ cycles) $^{43}$, is one of the most prevalent phase change materials."

These errors have now been corrected in the PDF and HTML versions of the Article.

(c) (i) Open Access This article is licensed under a Creative Commons Attribution 4.0 International (c) License, which permits use, sharing, adaptation, distribution and reproduction in any medium or format, as long as you give appropriate credit to the original author(s) and the source, provide a link to the Creative Commons license, and indicate if changes were made. The images or other third party material in this article are included in the article's Creative Commons license, unless indicated otherwise in a credit line to the material. If material is not included in the article's Creative Commons license and your intended use is not permitted by statutory regulation or exceeds the permitted use, you will need to obtain permission directly from the copyright holder. To view a copy of this license, visit http://creativecommons.org/licenses/by/4.0/.

(C) The Author(s) 2020 